\title{
CHARACTERIZATION OF PROTEINS AND FATTY ACID COMPOSITION IN GALAPAGOS FUR SEAL MILK. OCCURRENCE OF WHEY AND CASEIN PROTEIN POLYMORPHISMS
}

\author{
Fritz Trillmich, ${ }^{*}$ Dorothea KirChMEIER, $\dagger$ OTto KIRCHMEIER, $\dagger$ \\ INGOlF Krause, $\dagger \ddagger$ ERIKa LeChNER, $\dagger$ HeImo SCHERZ, $\ddagger$ \\ HaNS EICHINGER $\S$ and Markus SeEwald $\S$
}

*Max-Planck Institut für Verhaltensphysiologie, D-8131 Seewiesen, FRG (Tel.: 08157-29271);

†Südd. Versuchs- und Forschungsanstalt für Milchwirtschaft, Technische Universität München, Institut für Chemie und Physik, D-8050 Freising, FRG;

†Deutsche Forschungsanstalt für Lebensmittelchemie, Lichtenbergstraße 4, D-8046 Garching, FRG and §Institut für Tierzucht, Versuchsstation Thalhausen, Technische Hochschule München-Weihenstephan, D-8050 Freising, FRG

(Received 22 July 1987)

\begin{abstract}
Milk proteins of the Galapagos fur seal (Arctocephalus galapagoensis) were separated adequately into whey and casein fractions using bovine milk analysis methods.

2. In samples from days 5-30 of lactation $40 \%$ of the total proteins were whey and $60 \%$ caseins; in mid-lactation, day $150,25 \%$ were whey and $75 \%$ casein proteins.

3. Electrophoretic and isoelectric focusing patterns of fur seal whey protein differed widely from bovine patterns, whereas those of caseins were similar.

4. Polymorphisms of fur seal whey and casein proteins were noted and did not seem related to different stages of lactation.

5. C-16 and C-18 fatty acids contributed about $70 \%$ of fatty acids; $63 \%$ of the total acids in milk fat were unsaturated.
\end{abstract}

\section{INTRODUCTION}

The milk of marine mammals is unusually high in fat and protein (Jenness, 1974). While many data are now available of gross composition of such milk (Bonner, 1984; Oftedal et al., 1986) little is known about the specific protein and fatty acid composition (e.g. Ackman and Burgher, 1963; Ashworth et al., 1966; Horn and Baker, 1971; Jenness et al., 1981; Pilson and Kelly, 1962). Initially we also began with an analysis of the fat and protein content of the milk of the Galapagos fur seal (Arctocephalus galapagoensis) and sea lion (Zalophus californianus wollebaeki) and determined how milk composition changes with the age of the pup, and how the measured composition depends on the sampling method (Trillmich and Lechner, 1986). At the same time we began to investigate casein and non-protein nitrogen (NPN) content and tried to characterize proteins by polyacrylamide gel (PAG) electrophoresis. The electrophoresis showed differences in milk protein patterns between fur seal females (Kirchmeier, unpublished).

To determine whether the differences between our samples were due to polymorphisms or to the stage of lactation we took repeated samples from four fur seal females and an additional six mid-lactation samples in March 1987. These samples were analyzed by gel electrophoreses and isoelecric focusing to characterize protein fractions. We also investigated whether the separation methods used for bovine milk produce meaningful results when applied to fur seal milk (Jenness and Sloan, 1970) and obtained information on the fatty acids in the milk fat.

\section{MATERIALS AND METHODS}

Samples

Milk samples were obtained from Galapagos fur seal mothers (Arctocephalus galapagoensis) caught on Fernandina Island, Galapagos. The animals were briefly restrained for milking, injected intra-muscularly with $2 \mathrm{ml}$ of oxytocin (10 units $/ \mathrm{ml}$ ) and samples of $30-60 \mathrm{ml}$ were milked from one teat. Samples were immediately mixed with sodium azide and stored at ambient temperature $\left(\mathrm{ca} 22^{\circ} \mathrm{C}\right)$ before being shipped to Germany where they were deep frozen until analysis. Samples are listed in Table 1.

\section{Analytical methods}

Total nitrogen (TN) and non-protein nitrogen (NPN) were determined as described in Trillmich and Lechner (1986). Total protein nitrogen (TPN $=\mathrm{TN}-\mathrm{NPN}$ ) was determined as $\mathrm{ZnSO}_{4}$-precipitated nitrogen. Non-casein nitrogen (NCN) was nitrogen in the supernatant of milk

Table 1. Sources of Galapagos fur seal milk samples. Female numbers and age of pup (in days) at the time of milking

\begin{tabular}{|c|c|c|}
\hline Female & Age of pup & Year of sampling \\
\hline $\begin{array}{r}8 \\
11 \\
13 \\
14 \\
15\end{array}$ & $\begin{array}{r}1 \\
17 \\
30 \\
3 \\
14\end{array}$ & 1983 \\
\hline $\begin{array}{l}269 \\
271 \\
272 \\
273\end{array}$ & $\begin{array}{l}1,4,12 \\
1,6,12 \\
2,6,14 \\
1,5,15\end{array}$ & 1984 \\
\hline $1-6 / 87$ & $c a 150$ & 1987 \\
\hline
\end{tabular}


adjusted to $\mathrm{pH} 4.7$. Therefore, casein nitrogen $(\mathrm{CN})=$ $\mathrm{TN}-\mathrm{NCN}$, and whey protein nitrogen $(\mathrm{WPN})=\mathrm{TPN}-$ CN. Protein content was calculated by multiplying TPN, $\mathrm{CN}$ and WPN by the factor 6.38 .

\section{Electrophoresis}

After fat extraction cellulose acetate gel (CAG) electrophoresis was run for caseins in a phosphate-urea buffer $\left(0.92 \mathrm{~g}\right.$ citric acid monohydrate, $3.56 \mathrm{~g} \mathrm{Na}_{2} \mathrm{HPO}_{4}, 360 \mathrm{~g}$ urea, $1.5 \mathrm{ml}$ mercaptoethanol per $1000 \mathrm{ml}$ ) at $\mathrm{pH} 7.0$ $\left(4^{\circ} \mathrm{C}, 200 \mathrm{~V}, 3 \mathrm{hr}\right)$. Whey proteins were run on CAGs in a Tris-glycine buffer $(6.06 \mathrm{~g}$ Tris, $18.75 \mathrm{~g}$ glycine per $1000 \mathrm{ml})$ at $\mathrm{pH} 8.6\left(4^{\circ} \mathrm{C}, 200 \mathrm{~V}, 1 \mathrm{hr}\right)$. Proteins were stained with amido black.

Polyacrylamide gel (PAG) electrophoresis of milk proteins was performed according to application note 306 of the LKB-Instrument GmbH (D-8032 Gräfefing, FRG).

\section{Isoelectric focusing (IEF)}

Caseins were precipitated from defatted milk at $\mathrm{pH} 4.7$. The precipitate was extracted twice with dichloromethanewater (Krause et al., 1982) and the casein dried with acetone. Whey proteins were isolated by dialysis and lyophilization of the supernatant. Then $4 \mathrm{mg}$ of casein and $1 \mathrm{mg}$ of whey protein were dissolved in $1 \mathrm{ml}$ of $8 \mathrm{~mol} / 1$ urea and $0.03 \mathrm{~mol} / 1$ dithioerythritol (DTE) and applied to the PAG.

Alternatively, whole milk was defatted and urea was added to give a final concentration of $8 \mathrm{~mol} / \mathrm{l}$; the clear solution was diluted with $8 \mathrm{~mol} / 1$ urea containing $0.03 \mathrm{~mol} / 1$ DTE to protein concentrations suitable for isoelectric focusing (IEF). IEF was performed at $\mathrm{pH} 2.5-8.0$ in $4.7 \%$ PAGs $(260 \times 200 \times 0.25 \mathrm{~mm})$ in the presence of $7.5 \mathrm{~mol} / 1$ urea and $10 \%$ glycerol. The gel was run at $10^{\circ} \mathrm{C}$ with $7 \mathrm{~W}$ and a maximum voltage of $2500 \mathrm{~V}$ for $3.0 \mathrm{hr}$, including a $30 \mathrm{~min}$ pre-run (Krause, 1987; Krause and Belitz, 1985).

Approximately $60 \mu \mathrm{g}$ of caseins and $15 \mu \mathrm{g}$ of whey proteins were applied on the anodic side of the gel; the amount of protein in whole-milk samples varied. Proteins were stained with methanolic Servablue G 250 after fixation in $20 \%$ trichloroacetic acid. Isoelectric points $(\mathrm{p} I \mathrm{~s})$ of proteins were measured at $10^{\circ} \mathrm{C}$ with a surface electrode and compared with $\mathrm{p} I \mathrm{~s}$ of casein markers. No corrections were made for urea.

\section{Gas chromatographic analysis of fatty acids}

Fat extraction followed the method of Röse-Gottlieb (Horwitz, 1965). Transesterification of the fatty acids to methylesters was done according to Hadorn and Zürcher (1971). Capric acid methylester was added as an internal standard. Gas-liquid chromatography (GLC) of the methyl esters was carried out using hydrogen as a carrier gas on a Hewlett-Packard 5790 with a Durabond-wax capillary column of $30 \mathrm{~m}$ length (Diethylene glykol phase). The column was heated from 40 to $220^{\circ} \mathrm{C}$ at a rate of $10^{\circ} \mathrm{C} / \mathrm{min}$. The results are based on three GLC-runs.

\section{RESULTS}

\section{Protein composition and characterization}

Isoelectric precipitation at $\mathrm{pH} 4.7$ separated the proteins of the fur seal milk into two well-defined fractions. The precipitated proteins were shown to be caseins as they were sensitive to rennin (EC 3.4.23.4) treatment and only dissolved in urea buffer. The proteins in the supernatant fraction were coagulated by heat treatment, indicating that the fractionation procedure successfully separated the albumins and globulins (whey proteins) from the caseins (caseins have high heat stability).
Table 2. Protein composition of Galapagos fur seal milk. $\mathrm{NPN}=$ nonprotein nitrogen $(\mathrm{g} / 100 \mathrm{~g})$

\begin{tabular}{|c|c|c|c|c|c|c|}
\hline & $\begin{array}{c}\text { Total protein } \\
(\%)\end{array}$ & NPN & $\begin{array}{c}\text { Casein } \\
(\%)\end{array}$ & $\begin{array}{l}\text { Whey } \\
(\%)\end{array}$ & Female & $\begin{array}{l}\text { Age of pup } \\
\text { (days) }\end{array}$ \\
\hline & $\begin{array}{r}12.4 \\
7.9 \\
9.4 \\
9.1 \\
9.7 \\
10.2 \\
9.4 \\
11.8\end{array}$ & $\begin{array}{l}0.45 \\
0.26 \\
0.28 \\
0.21 \\
0.32 \\
0.15 \\
0.07 \\
0.12\end{array}$ & $\begin{array}{l}5.0 \\
4.5 \\
6.4 \\
4.9 \\
6.1 \\
5.4 \\
6.1 \\
7.5\end{array}$ & $\left.\begin{array}{l}7.4 \\
3.3 \\
3.0 \\
4.3 \\
3.6 \\
4.8 \\
3.3 \\
4.2\end{array}\right\}$ & $\begin{array}{r}272 \\
14 \\
15 \\
13\end{array}$ & $\begin{array}{r}1 \\
5 \\
15 \\
6 \\
14 \\
3 \\
14 \\
30\end{array}$ \\
\hline $\begin{array}{l}\text { Mean } \\
\text { SD }\end{array}$ & $\begin{array}{c}9.98 \\
1.46 \\
14.9 \\
14.6 \\
14.3 \\
12.2 \\
14.0 \\
13.8\end{array}$ & $\begin{array}{l}0.23 \\
0.12 \\
0.63 \\
0.71 \\
0.80 \\
0.48 \\
0.61 \\
0.73\end{array}$ & $\begin{array}{c}5.75 \\
0.99 \\
11.6 \\
10.5 \\
11.1 \\
8.1 \\
10.2 \\
11.5\end{array}$ & $\begin{array}{l}4.23 \\
1.42 \\
3.3 \\
4.1 \\
3.2 \\
4.1 \\
3.8 \\
2.3\end{array}$ & $\begin{array}{l}1 / 87 \\
2 / 87 \\
3 / 87 \\
4 / 87 \\
5 / 87 \\
6 / 87\end{array}$ & $\begin{array}{l}150 \\
150 \\
150 \\
150 \\
150 \\
150\end{array}$ \\
\hline $\begin{array}{l}\text { Mean } \\
\text { SD }\end{array}$ & $\begin{array}{c}14.0 \\
0.95\end{array}$ & $\begin{array}{l}0.66 \\
0.11\end{array}$ & $\begin{array}{r}10.5 \\
1.3\end{array}$ & $\begin{array}{l}3.5 \\
0.7\end{array}$ & & \\
\hline
\end{tabular}

Total nitrogen (TN) content of the milk was highest on the first day of lactation in three out of four females which were milked repeatedly. The means and SDs were: $2.39 \pm 0.33 \%$ on day 1 , $N=4 ; \quad 1.85 \pm 0.31$ day $3-30, N=8 ; \quad(P=0.048$, Mann Whitney $U$-test). This was mainly due to a higher whey protein and NPN content on day 1. While whey protein remained nearly constant after the first day of lactation (Table 2), casein increased up to day 150 (regression: casein $(\%)=0.035 d+$ 5.32; $d=$ age of pup in days; $r=0.93, P<0.001$ ). Over the first 30 days of lactation the amount of casein in the milk increased by over 50\% (Table 2). This fits with the reported increase in milk Ca-content with age of the pup (Trillmich and Lechner, 1986). By day 150 of lactation caseins had roughly doubled. In milk samples from days 5-30 of lactation, caseins contributed $61.9 \pm 5.5 \%$ (mean \pm SD) and whey proteins $38.1 \pm 5.5 \%$ of the milk proteins, giving a ratio of roughly $1.6: 1$, by day 150 this had changed to $75 \%$ caseins and $25 \%$ whey, 3:1 (Table 2).

IEF showed that the fur seal's casein fractions were similar to those of cow's or other ruminants' milk (Fig. 1). However, since the amino acid sequence of fur seal caseins was not determined, true homology could not be established. Therefore casein fractions were provisionally assigned roman numerals; arabic numbers were assigned to the protein components of each fraction in order of increasing mobility of $\mathrm{p} I \mathrm{~s}$ as recommended by Eigel $e t$ al. (1984). Latin letters were used for obvious polymorphisms. Where similarity seemed clear the corresponding name of the bovine milk protein fraction is mentioned.

\section{Caseins}

Cn-I (similar to alpha-sl-casein) had a $\mathrm{p} I$ of 4.9 and the second fraction-Cn-II $(\beta-\mathrm{Cn}$ like)--was a variable group with up to four zones with $\mathrm{p} / \mathrm{s}$ of $5.5,5.55,5.6$, and 5.7. Cn-III with a $\mathrm{p} I$ of around 6.0 (Figs 1 and 2) seemed to be a k-casein, judging from its sensitivity to rennin (EC 3.4.23.4). The minor casein fraction with $\mathrm{p} / \mathrm{s}$ above 6.3 (Fig. 1) were collectively labeled Cn-IV and may be similar to the bovine $\gamma$-caseins. 


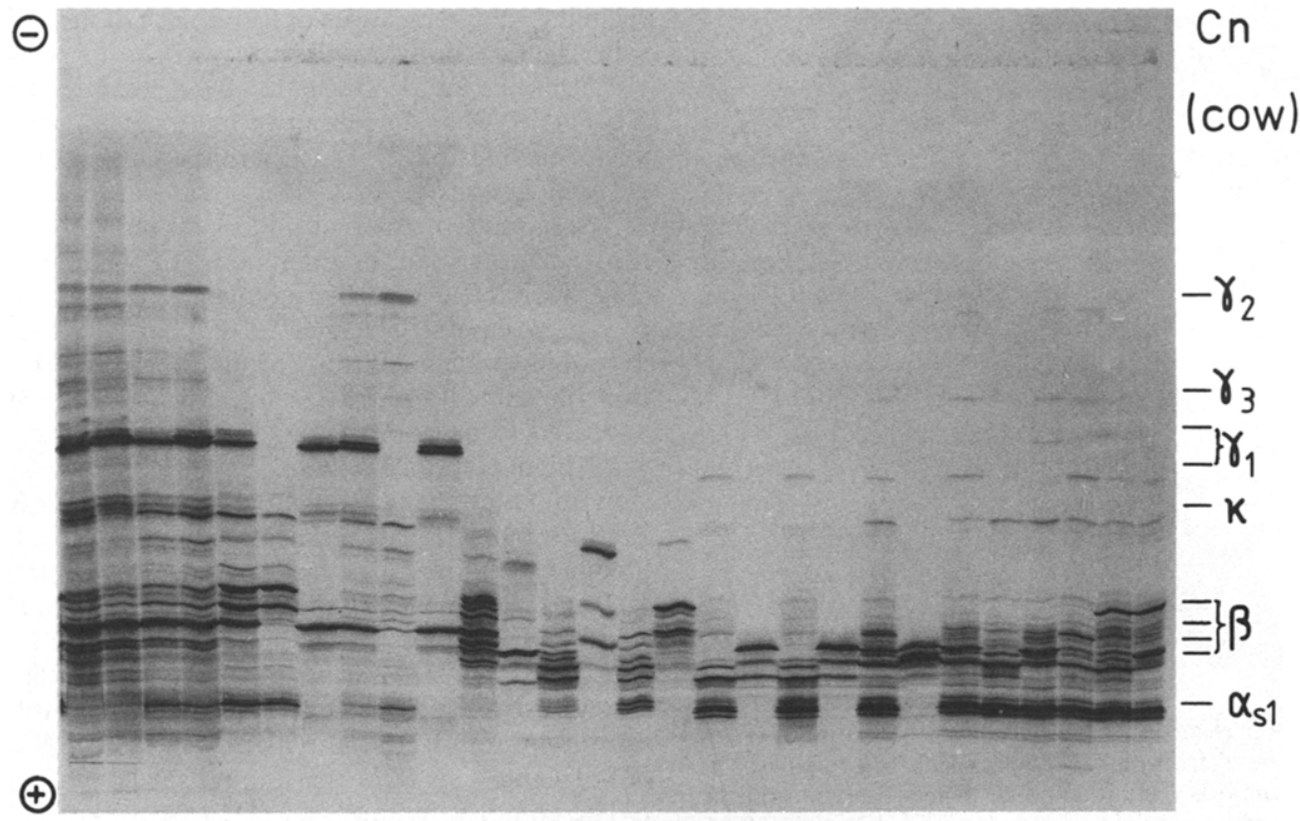

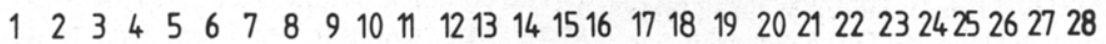

Fig. 1. Thin-layer IEF of Galapagos fur seal milk in comparison to those of other species and to marker proteins. $\mathrm{M}=$ whole milk, $\mathrm{C}=$ casein fraction, $\mathrm{W}=$ whey fraction. First number = female number; last number $=$ pup age (days). $\mathrm{Cn}=$ casein. Nos $21-26$ bovine casein markers. Position 1: 269, M, 1; 2: 271, M, 1; 3: 269, M, 4; 4: 271, M, 6; 5: 269, M, 12; 6: 269, C, 12; 7:269, W, 12; 8: 271, M, 12; 9: 271, C, 12; 10: 271, W, 12; 11: C, horse; 12: W, horse; 13: C, goat; 14: W, goat; 15: C, sheep; 16: W, sheep; 17 19: $\mathrm{C}$, water buffalo; 18, 20: W, water buffalo; $21: \mathrm{C}$, cow; $22: \mathrm{W}$, cow; 23 : C-marker with $\beta$-Cn A2/A1; 24: C-marker with $\beta$-Cn A2; 25: C-marker with $\beta$-Cn A1; 26: C-marker with $\beta$-Cn A2/B; 27: C-marker with $\beta-\mathrm{Cn} \mathrm{A2/C;} \mathrm{28:} \mathrm{C-marker} \mathrm{with} \beta-\mathrm{Cn} \mathrm{A1/C}$.

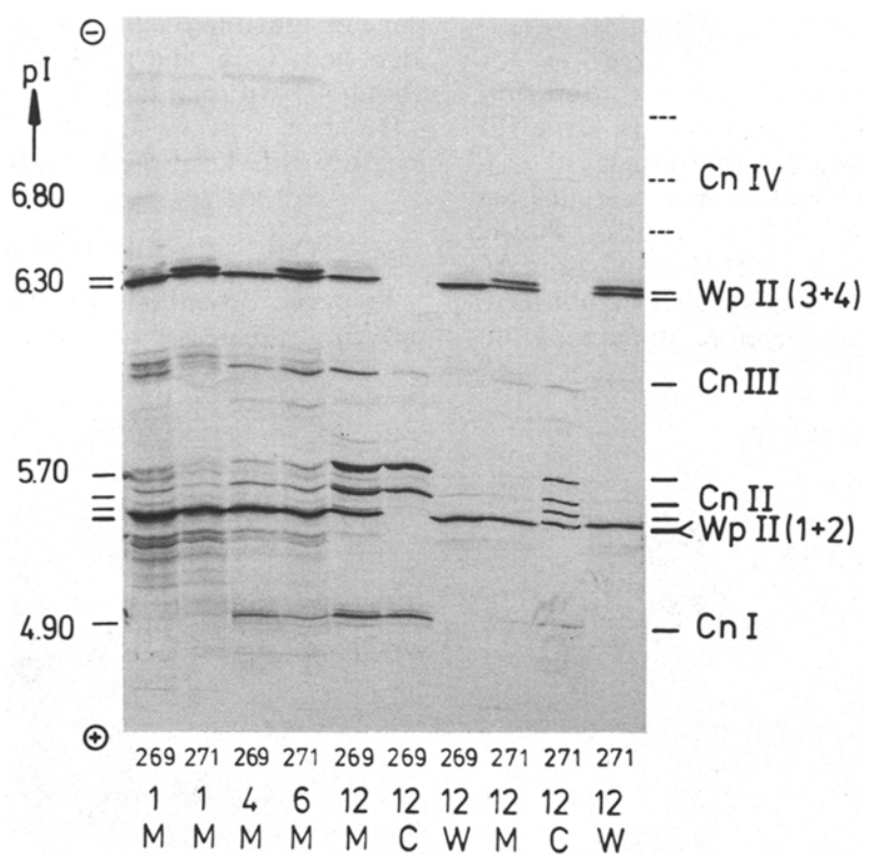

Fig. 2. Thin-layer IEF of whole milks, caseins and whey proteins from Galapagos fur seal females 269 and 271 . Symbols; upper line, female number; middle line, age of pup in days; lower line, abbreviations as in Fig. 1. 

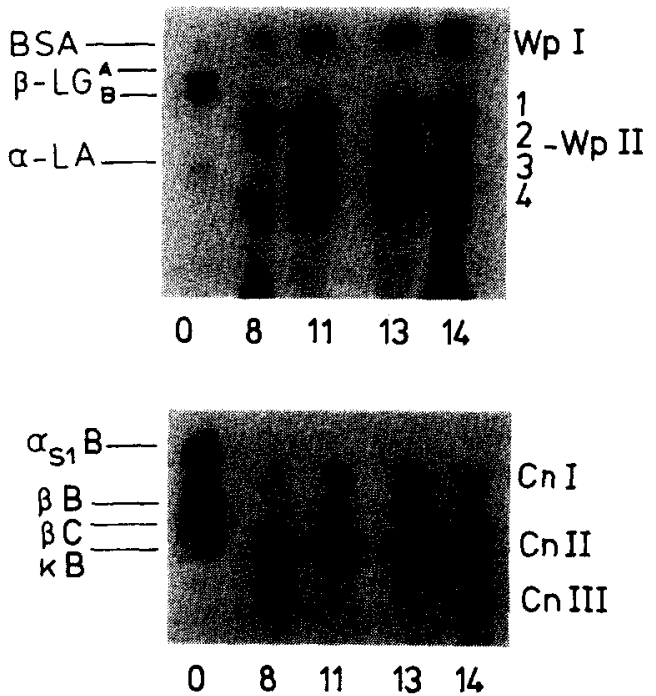

Fig. 3. CAG electrophoresis of whey proteins (above) and caseins (below) from Galapagos fur seals in comparison to bovine standards $(0)$ with known genetic polymorphisms. Numbers refer to individual females milked in 1983 (Table 1). $\mathrm{BSA}=$ bovine serum albumin. $\beta-\mathrm{LG}=\beta$-lactoglobulins $A$ and B. $\alpha-L A=\alpha$-lactalbumin.

\section{Whey proteins}

Wp-I (similar to bovine serum albumin = BSA) had a high mobility and could only be resolved in $\mathrm{CAG}$ electrophoresis. The $\mathrm{p} / \mathrm{s}$ of proteins in the major whey protein fraction Wp-II were 5.5 (Wp-II, 1), 6.29 (Wp-II, 3) and 6.31 (Wp-II, 4) (Fig. 2). The more basic fraction corresponded to the slowest moving component in CAG electrophoresis. In CAG electrophoresis, Wp-II consisted of up to four well-separated protein zones (Figs 3-5).

\section{Protein polymorphisms}

Individual females always displayed the same IEF and electrophoretic protein pattern from days 1 to 12 or 15 of lactation (Figs 2 and 5 for females 269 and 271). However, milk of different females showed variable banding patterns in IEF (Fig. 2), CAG (Figs 3-5) and PAG electrophoresis (unpublished). The variants found are therefore apparently not related to different stages of lactation, but more likely reflect genetic polymorphisms.

Within the Wp-II group, the four clearly separated bands (Figs 3-5) suggest a two locus system with two alleles each (Table 3). Wp-I (serum albumin) seems to be homogenous.

The caseins of fur seal milk were more similar to those of other species than were the whey proteins (Fig. 1). Thus a tentative nomenclature of alpha-s-, $\beta-$, and $\mathrm{k}$-caseins is suggested. CAG electrophoresis indicated polymorphism forms in the $\mathrm{Cn}-\mathrm{I}$ fraction (presumed alpha-s-casein) (Fig. 4). Female 272 appeared to be homozygous for a more acidic form with higher mobility (Cn-I, 1) while female 273 showed a more basic band with lower mobility (Cn-I, 2). Both bands were present in animals 269 and 271 . Stronger banding of the homozygous state in females 272 and 273 agrees with the expected dose effect. These polymorphic forms were not separated in IEF and had a single band at $\mathrm{p} I 4.9$; however, the IEF system used also does not separate bovine alpha-slcasein variants $B$ and $C$ which have close $p I$-values of 4.92 and 4.95 (Krause, unpublished).

The complex pattern of Cn-II ( $\beta$-Cn-like) did not allow any clear interpretation. One to four bands were recognizable in CAG electrophoresis (Fig. 4) although separation was not as clear as for the whey proteins. In IEF, milk of female 269 had only two bands of Cn-II (pI 5.6 and 5.7) whereas the milk of female 271 showed a further two, which were more acidic components with $\mathrm{p} I \mathrm{~s}$ of 5.5 and 5.55 (Fig. 2). Cn-III (k-Cn) seemed to be homogenous.

\section{Fatty acid composition}

Three GLC runs were averaged to give the values in Table 4. Only area per cent are given as the identity of a few peaks out of the 22 could not be ascertained due to the lack of standards. Eight minor components, totalling $5.6 \%$ of peak areas, were not identified. C-16 and C-18 fatty acids contributed about $70 \%$ of total fatty acids and $63 \%$ of the total fatty acids were unsaturated. The minimum chain length was $\mathrm{C}-12$ and the maximum $\mathrm{C}-22$.

\section{DISCUSSION}

Preparative methods developed for bovine milk proved adequate for the separation of fur seal whey
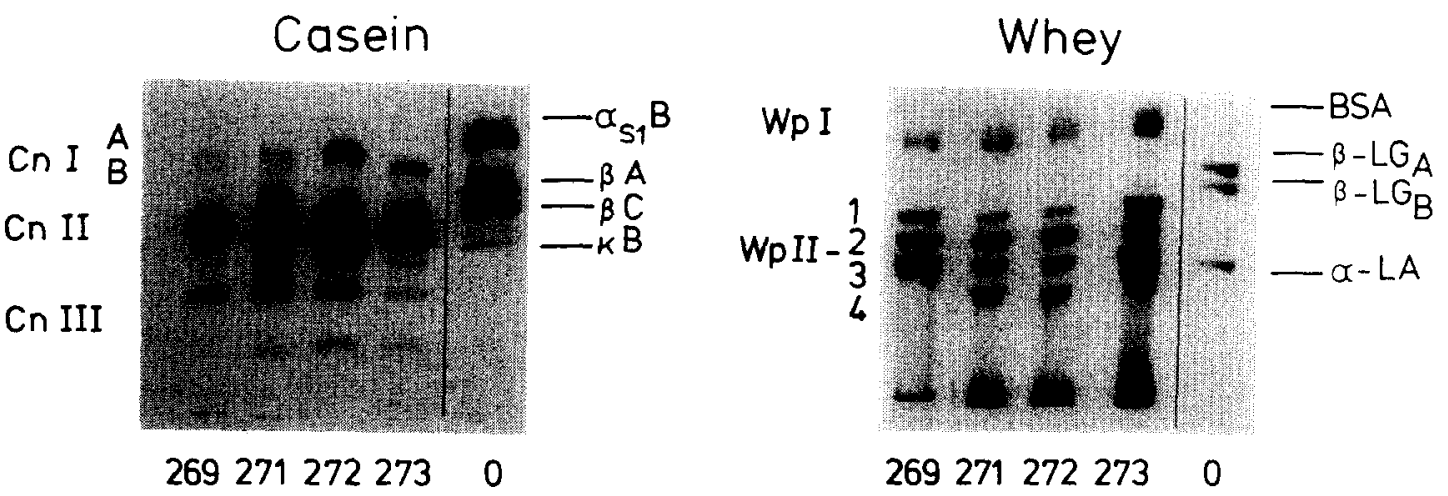

Fig. 4. Comparison of the CAG banding pattern of caseins and whey proteins of the females milked in 1984. $0=$ bovine standard, other abbreviations as in Fig. 3. 


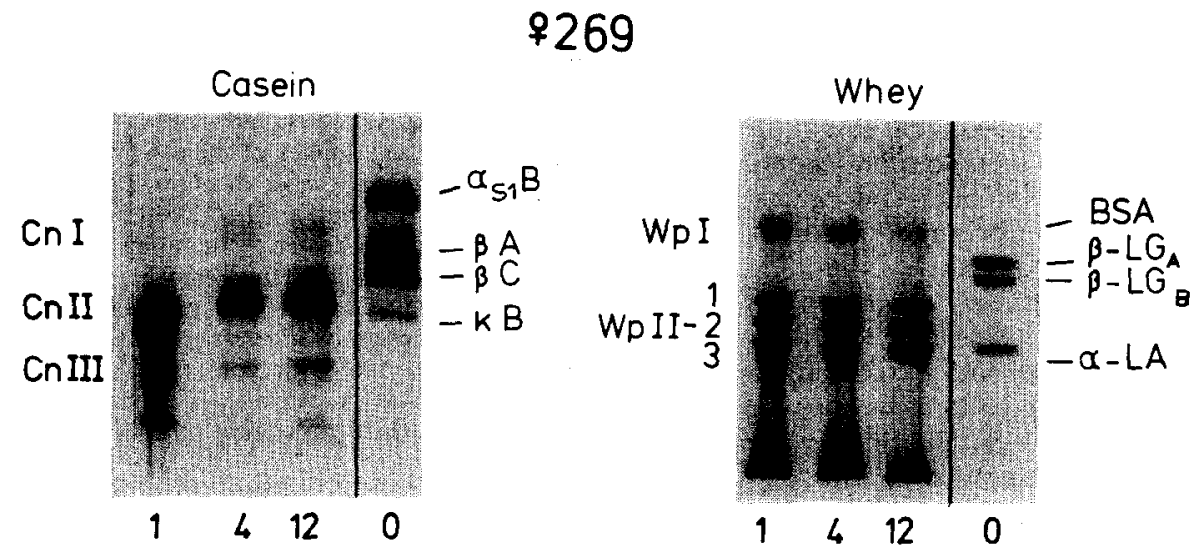

\section{$\$ 271$}
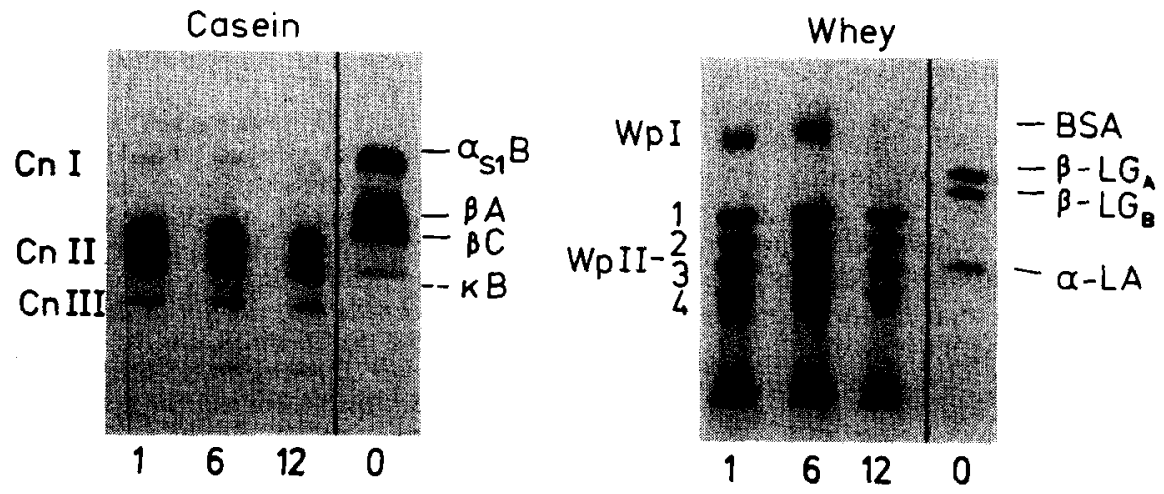

Fig. 5. CAG electrophoresis of caseins and whey proteins of the milk of females 269 and 271. At various stages of lactation banding patterns are always the same. $0=$ bovine standard; other numbers =age of pup. Other abbreviations as in Fig. 3.

and casein. The pattern of change in the ratio of casein to whey protein in initial lactation corresponds to that found in many other mammals where, initially, relatively more whey proteins are produced, presumably to transfer immunoglobulins to the young (Cavagnolo and Vedros, 1979; Oftedal, 1984). Caseins became more predominant later in lactation. The 1.6:1 ratio between casein and whey in the Galapagos fur seal milk roughly agrees with data on phocid milks (Jenness and Sloan, 1970) and Northern fur seal milk (Ashworth et al., 1966), but the 3:1 ratio on day 150 is clearly higher. The NPN-values in Table 2 may be slight overestimates since the samples were preserved with $\mathrm{Na}$-azide, initially at room temperature, and so milk proteases may have degraded proteins a little.

Table 3. Whey protein variants in $\mathrm{Wp}-\mathrm{II}$, in order of diminishing mobility, as found in the milk of eight fur seals

\begin{tabular}{lcccccccccc}
\hline & & \multicolumn{1}{c}{ Female number } \\
& Component & 8 & 11 & 13 & 14 & 269 & 271 & 272 & 273 \\
\hline Whey & 1 & + & + & + & + & + & + & + & + \\
Protein & 2 & + & + & + & - & + & + & + & + \\
Variants & 3 & - & + & + & + & + & + & + & + \\
& 4 & + & + & + & + & - & + & + & - \\
\hline
\end{tabular}

Table 4. Fatty acid composition of milk fat from Galapagos fur seals. Average of three GLC-runs (in area per cent). $x=$ unidentified fatty acid

\begin{tabular}{cccc}
\hline Peak no. & $\begin{array}{c}\text { Retention time } \\
(\text { min })\end{array}$ & Fatty acid & Area per cent \\
\hline 1 & 12.43 & $\mathrm{x}$ & 0.27 \\
2 & 13.47 & $\mathrm{x}$ & 0.27 \\
3 & 14.57 & $\mathrm{C} 14: 0$ & 3.18 \\
4 & 15.62 & $\mathrm{x}$ & 0.61 \\
5 & 16.72 & $\mathrm{C} 16: 0$ & 20.75 \\
6 & 16.93 & $\mathrm{C} 16: 1$ & 5.65 \\
7 & 17.53 & $\mathrm{x}$ & 0.76 \\
8 & 17.63 & $\mathrm{C} 17: 0$ & 0.60 \\
9 & 17.85 & $\mathrm{x}$ & 1.09 \\
10 & 18.63 & $\mathrm{C} 18: 0$ & 2.40 \\
11 & 18.84 & $\mathrm{C} 18: 1$ & 40.65 \\
12 & 19.19 & $\mathrm{C} 18: 2$ & 1.41 \\
13 & 19.76 & $\mathrm{C} 18: 3$ & 0.28 \\
14 & 20.35 & $\mathrm{C} 20: 0$ & 0.08 \\
15 & 20.53 & $\mathrm{C} 20: 1$ & 2.02 \\
16 & 21.37 & $\mathrm{C} 20: 4$ & 1.82 \\
17 & 21.92 & $\mathrm{C} 20: 5$ & 1.97 \\
18 & 22.17 & $\mathrm{C} 22: 2$ & 0.10 \\
19 & 23.09 & $\mathrm{x}$ & 0.45 \\
20 & 23.37 & $\mathrm{x}$ & 0.57 \\
21 & 23.76 & $\mathrm{x}(\mathrm{C} 22: 5 ?)$ & 1.57 \\
22 & 24.10 & $\mathrm{C} 22: 6$ & 6.12 \\
\hline
\end{tabular}


Even tentative homologization of fur seal milk whey components with those of bovine milk seems premature, except perhaps for blood serum albumin. Alpha-lactalbumin appeared to be absent, which is as expected since fur seal milk does not contain lactose (Schmidt et al., 1971; Trillmich and Lechner, 1986). Fur seal caseins were surprisingly similar to those of artiodactyls (Fig. 1). Nevertheless the homology remains speculative until sequencing proves genetic homology (Eigel et al., 1984).

The variants of whey and casein proteins in the electrophoretic banding patterns were apparently not related to the stage of lactation. Such polymorphism in milk proteins may be a valuable addition to studies of genetic differences between seal populations since seal blood proteins generally show little genetic variation (Lidicker et al., 1981; Testa, 1986). Similar polymorphisms of whey proteins were previously described by Shaughnessy (1974) for the Southern elephant seal.

The fatty acid composition is similar to that in other pinnipeds where palmitic (16:0), palmitoleic (16:1), and oleic acid (18:1) also preodminate (Oftedal et al., 1986). Possible influences of dietary lipids on milk fatty acid composition have been discussed previously (Ashworth et al., 1966; Stull et al., 1967; van Horn and Baker, 1971), but cannot be substantiated for the Galapagos fur seal as we lack data on fatty acids in their food organisms. The broad pattern of long chain, unsaturated fatty acids seems to be typical for carnivora in general (Glass $e t$ al., 1967).

Acknowledgements - We would like to thank T. Dellinger, C. Drews, G. L. Kooyman, P. Thorson and K. Trillmich for their help in getting the samples. The support of the Galapagos National Park through its Intendente Miguel Cifuentes, and of the Charles Darwin Station through its directors C. MacFarland, H. Hoeck and G. Reck are gratefully acknowledged. D. Schmidl expertly prepared the graphs and Lesley Ward kindly corrected the English. This study was financed by the Max-Planck Gesellschaft and W. Wickler's constant support of the fur seal project is most gratefully acknowledged.

\section{REFERENCES}

Ackman R. G. and Burgher R. D. (1963) Component fatty acids of the milk of the grey (Atlantic) seal. Can. J. Biochem. Physiol. 41, 2501-2505.

Ashworth U. S., Ramaiah G. D. and Keyes M. C. (1966) Species difference in the composition of milk with special reference to the northern fur seal. J. Dairy Sci. 49, 1206-1211.

Bonner W. N. (1984) Lactation strategies in pinnipeds: problems for a marine mammalian group. Symp. Zool. Soc. Lond. 51, 253-272.

Cavagnolo R. Z. and Vedros N. A. (1979) Serum and colostrum immunoglobulin levels in the Northern fur seal Callorhinus ursinus. Devl Comp. Immunol. 3, 139-146.

Eigel W. N., Butler J. E., Ernstrom C. A., Farrell H. M. Jr.,
Harwalkar V. R., Jenness R. and Whitney R. McL. (1984) Nomenclature of proteins of cow's milk: fifth revision. J. Dairy Sci. 67, 1599-1631.

Glass R. L., Troolin H. A. and Jenness R. (1967) Comparative biochemical studies of milks-IV. Constituent fatty acids of milk fats. Comp. Biochem. Physiol. 22, 415425 .

Hadorn H. and Zürcher K. (1971) Fettsäureverteilung sowie Milchfett- und Kokosfettbestimmung in Fetten, Olen und fetthaltigen Lebensmitteln; Gehaltsbestimmung mit Hilfe chemischer Kennzahlen und der Gaschromatographie. Mitt. Geb. Lebensmittelunters. Hyg. 62, 123-151.

van Horn D. R. and Baker B. E. (1971) Seal milk II. Harp seal (Pagophilus groenlandicus) milk: effects of stage of lactation on the composition of milk. Can. J. Zool. 49, 1085-1088.

Horwitz W. (ed.) (1965) Official Methods of Analysis of the $A O A C$, 10th edn. AOAC, Washington, DC.

Jenness R. (1974) The composition of milk. In Lactation, Vol. III (Edited by Larsen B. L. and Smith V. R.), pp. 3-107. Academic Press, New York

Jenness R. and Sloan R. E. (1970) The composition of milks of various species: a review. Dairy Sci. Abstr. 32, 599-612.

Jenness R., Williams D. and Mulin R. J. (198I) Composition of milk of the sea otter. Comp. Biochem. Physiol. 70A, 375-379.

Krause I. (1987) Untersuchungen zum Nachweis von Kuhmilch in Schaf-, Ziegen- und Büffelmilch bzw.-käse. Ph.D. Thesis, Technische Universität, München.

Krause I. and Belitz H. D. (1985) Differenzierung von Milchproteinen verschiedener Tierarten: Nachweis von Kuhmilch in Schaf-, Ziegen- und Büffelmilch bzw.-käse. Lebensmittelchem. Gerichtl. Chem. 39, 33-36.

Krause I., Belitz H.-D. and Kaiser K.-P. (1982) Nachweis von Kuhmilch in Schaf- und Ziegenmilch bzw.-käse durch isoelektrische Fokussierung in harnstoffhaltigen Polyacrylamidgelen. Z. Lebensm. Unters. Forsch. 174, 195-199.

Lidicker W. Z. Jr., Sage R. D. and Calkins D. G. (1981) Biochemical variation in northern sea lions from Alaska. In Mammalian Population Genetics (Edited by Smith M. H. and Joule J.), pp. 231-241. University of Georgia Press, Athens.

Oftedal O. T. (1984) Milk composition, milk yield and energy output at peak lactation: a comparative review. Symp. Zool. Soc., Lond. 51, 33-85.

Oftedal O. T., Boness D. J. and Tedman R. A. (1986) The behavior, physiology and anatomy of lactation in the pinnipedia. Curr. Mammal. 1, 175-245.

Pilson M. E. Q. and Kelly A. L. (1962) Composition of the milk from Zalophus californianus, the Californian sea lion. Science 135, 104-105.

Schmidt D. V., Walker L. E. and Ebner K. E. (1971) Lactose synthetase activity in Northern fur seal milk. Biochim. biophys, Acta 252, 439-442.

Shaughnessy P. D. (1974) An electrophoretic study of blood and milk proteins of the southern elephant seal, Mirounga leonina. J. Mammal. 55, 796-808.

Stull J. W., Brown W. H. and Kooyman G. L. (1967) Lipids of the Weddell seal, Leptonychotes weddelli. J. Mammal. 48, 642-645.

Testa J. W. (1986) Electropmorph variation in Weddell seals (Leptonychotes weddelli). J. Mammal. 67, 606-610.

Trillmich F. and Lechner E. (1986) Milk of the Galapagos fur seal and sea lion, with a comparison of the milk of eared seals (Otarridae). J. Zool., Lond. 209, 271-277. 